\title{
Pengembangan Video Sebagai Media Pembelajaran dalam Meningkatkan Kemampuan Berpikir Analisis Siswa Pada Pembelajaran Sosiologi Kelas XI IPS SMAN 1 Payakumbuh
}

\author{
Sriyani Amsar ${ }^{1}$, Ike Sylvia ${ }^{2}$ AB Sarca Putera ${ }^{3}$ \\ 1,2,3 Universitas Negeri Padang \\ Email: sriyaniamsar010698@gmail.com, $\underline{\text { ikesylvia@fis.unp.ac.id, absarcaputera@fis.unp.ac.id }}$
}

\begin{abstract}
Abstrak
Penelitian dilaksanakan bertujuaan membuat dan mengembangkan media berbasis audio visual mengenai materi integrasi sosial yang layak digunakan dari segi validitas, praktikalitas dan efektifitas. Pengembangan media audio visual yang dikembangkan bertujuan meningkatkan kemampuan berpikir analisis pada mata pelajaran sosiologi kelas XI. Media pembelajaran berbasis video dirasa cukup efektif digunakan, karena memiliki pengaruh yang terhadap daya tarik siswa untuk mempelajari kompetensi yang diajarkan. Jenis penelitian yang digunakan adalah Reserch and Development $(\mathrm{R} \& \mathrm{D})$. Model yang digunakan adalah model pengembangan ADDIE milik Dick and Carry. Uji coba produk dilakukan pada siswa kelas XI SMAN 1 Payakumbuh dengan jumlah 33 peserta didik. Kelayakan produk ini dari segi validitas telah diuji oleh dua orang ahli media dan 1 orang ahli materi. Terakhir untuk menguji keefektifan media didapatkan dari perbandingan t-hitung $>$ t-tabel yang artinya media pembelajaran berbasis video layak digunakan sebagai media pembelajaran dalam meningkatkan kemampuan analisis peserta didik pada mata pelajaran Sosiologi.
\end{abstract}

Kata kunci: Kemampuan Berpikir Analisis, Media Pembelajaran, Video.

\section{Abstract}

This research was conducted to produce a development product in the form of a video based learning media about social integration material that is feasible to use in term of validity, practicality and effectiveness. The plot of video media is design to be as improve analitycal thinking skills in class XI sociology subjects. Video based learning media are considered quite effective in use, because it has a significant influence on the attractiveennes of student to learn the competenciens being taught. The type of research and development (R\&D). The model used is Dick and Carry's ADDIE development model. Product trials were conducted on grade XI students of SMAN 1 Payakumbuh with a total of 33 student. The feasibillity of this product in term of validity has been tasted by two media expert and 1 material expert. Finally, to test the effectiveness of the media it is obtained the comparison of tcount>ttable, which means that video based learning media are effectively used as learning media in improving students analytical thinking skills in sociology subjects.

Keywords: Analytical Thinking, Skills Learning Media, Video

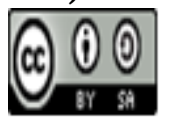

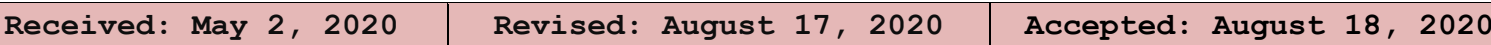

Jurnal Sikola: Jurnal Kajian Pendidikan dan Pembelajaran Vol. 2, No. 1, Th. 2020 


\section{Pendahuluan}

Pembelajaran Sosiologi sebagai salah satu pembelajaran yang bersifat abstrak tidak cukup disampaikan dengan teori dan menemukan jawaban saja, namun perlu adanya media karena pada pendidikan abad 21 media yang digunakan harus menuntut peserta didik pada critical thinking dan problem solving, creativity, innovation, communication, collaboration serta global awarenesss (Marjohan, 2013). Dalam pembelajaran sosiologi SMA siswa tidak hanya memahami konsep dan teori akan tetapi siswa diharapkan mampu bekerjasama ataupun keaktifan dalam pemebelajaran (Vermana \& Sylvia, 2019). Salah satu cara untuk mewujudkan tujuan pendidikan abad 21 ini ialah dengan meningkatkan kemampuan berpikir anaalisis pada siswa melalui pemilihan media pembelajaran dengan memanfaatkan perkembangan teknologi. Oleh karena perkembangan dan ilmu teknologi, khususnya ICT, seorang guru Sosiologi seharusnya mampu memilih media pembelajaran yang lebih menarik dengan memanfaatkan teknologi yang ada sehingga bisa meningkatkan pemahaman peserta didik. (Putri \& Sutrisno, 2013)

(Sukiman, 2012), menjelaskan bahwa media pembelajaran ialah segala sesuatu yang digunakan untuk menyalurkan pesan dari pengirim ke penerima sehingga merangsang pikiran, perasaan, perhatian, dan minat serta kemauan peserta didik sehingga proses belajar terjadi dalam rangka mencapai tujuan pembelajaran secara efektif. Gerlach dan Ely dalam Rusman (Rusman, 2013), ada beberapa ciri media merupakan petunjuk mengapa media digunakan dan apa saja yang dapat dilakukan oleh media yakni cirri fiksatif, ciri manipulasi dan ciri distributif.

Hasil belajar peserta didik dilihat dari kemampuan berpikir analisis peserta didik dalam proses pembelajaran. Kemampuan analisis adalah kemampuan untuk menguraikan elemen, unsur, faktor dan sebab-sebab dari suatu fenomena(munthe, 2009). Semakin jelas bahwa guru dituntut untuk lebih aktif dan inovatif dalam menguasai pembelajaran di kelas yang mampu meningkatkan kemampuaan berpikir tingkat tinggi baik model, metode maupun media pembelajaran. Dengan demikian guru harus memilih media yang sesuai dengan materi yang akan disampaikan. (Arsyad, 2011), media adalah manusia, materi dan kejadian yang membangun sebuah kondisi siswa mampu memperoleh pengetahuan, keterampilan dan sikap.

Kenyataannya berdasarkan hasil pengamatan dan wawancara langsung dengan guru SMA N 1 Payakumbuh menunjukan bahwa kemampuan siswa dalam memecahkan masih kurang karna siswa kurang mampu mengidentifikasi, mengkaitkan, membedakan, mempertentangkan, serta menentukan faktor sebab akibat dalam pembelajaran kurang menarik perhatian peserta didik. Siswa hanya menerima materi dari guru atau dalam kata lain proses pembelajaran masih berpusat pada guru.

Dari permasalahan di atas peneliti melihat bahwa pengembangan media pembelajaran berbasis audio video perlu dilakukan dalam meningkatkan kemampuan berpikir analisis siswa. Media video adalah media yang dapat menarik perhatian siswa karena mengandung unsur melihat dan mendengarkan dan suara) dan dilengkapi dengan suara penuntun yang mudah dimengerti dan dipahami oleh peserta didik (Niswah, 2012). Video pembelajaran dirancang sebagai media yang efektif. Berisi materi praktis yang tepat sasaran, disajikan dalam bentuk audio dan visual. (Munir, 2012) video merupakan sumber belajar yang menarik dan efektif dalam menyampaikan informasi, karena penggunaan video dalam multimedia interaktif akan memberikan pengalaman baru. Dale mengatakan media audio visual adalah media pembelajaran dan media pendidikan yang mengaktifkan mata dan telinga peserta didik dalam waktu proses belajar mengajar berlangsung. (Arsyad, 2011) menyatakan bahwa media audio visual merupakan media yang mengandung unsur gambar yang bisa dilihat, seperti rekaman video, berbagai ukuran film, slide suara dan lain sebagainya. Kemampuan media ini lebih baik dan lebih menarik, karena memiliki dua unsur jenis media (Sanjaya, 2009). Media pembelajaran inilah yang akan membantu memudahkan peserta didik dalam mmproses informasi pengetahuan yang disampaikan. Menurut Rudi Bertz dalam(Arsyad, 2011). mengklasifikasikan ciri utama 
media yaitu suara, visual, dan gerak. Bentuk visual itu sendiri dibedakan lagi pada tiga bentuk, yaitu gambar visual, garis, dan symbol. Seperti umumnya media sejenis media audio visual mempunyai tingkat effektifitas yang cukup tinggi, menurut riset, rata-rata di atas $60 \%$ sampai $80 \%$. Pembelajaran melalui audio video visual jelas bercirikan pemakaian perangkat keras selama proses belajar, seperti proyektor film, televisi, tape recorder dan proyektor visual yang lebar.

Menurut (Harjanto, 2005) kelebihan dari media audio visual seperti bahan ajar akan jelas maknanya sehingga dapat lebih dipahami oleh para siswa, dan membuat peserta didik menguasai tujuan pelajaran, mengajar akan lebih bervariasi, tidak semata-mata komunikasi verbal melalui penuturan kata-kata oleh guru, hingga peserta didik tidk merasa jenuh dalam belajar, serta pembelajaran akan dapat menumbuhkan motivasi belajar. Media ini memiliki beberapa kekurangan yakni pendengar cuma dapat dipahami oleh orang yang mempunyai tingkat penguasaan kata dan bahasa yang baik, penyajian materi melalui media audio visual dapat menimbulkan verbalisme bagi pendengar (Sanjaya, 2009).

\section{Metode Penelitian}

Penelitian ini menggunakan metod Research \& Development (R\&D). Menurut Sugiyono (Sugiyono, 2013) metode ini ialah suatu cara dalam menghasilkan sebuah produk dan melihat keefektifan produk tersebut. Menurut Puslitjaknov (Putra, 2012) hal dasar dalam model pengembangan ini berupa prosedur, konsep dan teori. Dan pada penelitian yang penulis lakukan penulis memilih model prosedur karna lebih cocok dengan tujuan penelitian.

Peneliti menggunakan model pengembangan yang dimiliki oleh Dick \& Carry yang disebut dengan ADDIE. Model ini pengembangannya secara sistematis serta berlandaskan pada teoritis selain itu model ini juga dapat dipahami lebih mudah. Menurut Sugiono (Sugiyono, 2013) penyusunan model ini terprogram dengan upaya pemecahan masalah yang berkaitan dengan media pembelajaran. Tahap-tahap dalam penggunaan model ini ada 5 tahap yaitu (1) tahap analisis, pada tahap ini peneliti melakukan proses pengumpulan informasi yang dijadikan sebagai bahan untuk membuat produk. Pengumpulan informasi ini berupa analisis kebutuhan analisis perangkat keras, dan perangkat lunak dalam pembuatan produk. (2) Tahap perencanaan, pada tahap ini peneliti akan membuat semua hal yang dibutuhkan sesuai dengan yang ada pada tahap analisis. Semua mulai direaalisasikan untuk menghasilkan sebuah produk yang dapat digunakan dalam kegiatan pembelajaran. (3) Tahap pengembangan, Menurut Branch (Branch, 2009) adalah media yang telah dibuat aakan dikembangkan sesuai dengan kritik dan saran yang telah diberikan oleh ahli edia dan materi. (4) Tahap implementasi, pada tahap ini adalah tahappenerapan produkyang telah dibuat dan diuji cobakan pada kehidupan. (5) Tahap evaluasi, tahap ini dilaksanakan pada masing-masing tahap yang tujuannya adaalah unttuk menyempurnakan tahap-tahap sebelumnya sehingga menghasilkan produk yang layak untuk dipakai.

Instrumen penelitian instrumen validasi produk dan angket. Ada tiga angket yang dikembangkan untuk melihat validitas materi, media dan keefektifan produk diantaranya angket untuk ahli media, ahli materi dan untuk peserta didik yang dijadikan sampel kelas XI yang mempelajari materi integrasi sosial sesuai dengan video yang peneliti kembangkan untuk mengukur keefektifan media video sebagai media pembelajaran sosiologi.

Teknik analisis data menggunakan rumus analisis validitas dengan mencari rata-rata empiris dengan menggunakan rumus:

$$
x=\frac{\sum x}{\mathrm{n}}
$$

Jurnal Sikola: Jurnal Kajian Pendidikan dan Pembelajaran Vol. 2, No. 1, Th. 2020 


$$
\begin{aligned}
& \text { Keterangan: } \\
& \mathrm{x}=\text { rata }- \text { rata } \\
& \sum x=\text { jumlah nilai } \\
& \mathrm{n}=\text { jumlah responden }
\end{aligned}
$$

Untuk menghitung persentase dari tiap- tiap subvariabel dengan rumus:

$$
\begin{aligned}
& P(s)=\frac{s}{N} \times 100 \% \\
& \text { Keterangan: } \\
& P(s) \quad=\text { persentase sub variable } \\
& \mathrm{S}=\text { Jumlah skor tiap sub variable } \\
& \mathrm{N} \quad=\text { Jumlah skor maksimun }
\end{aligned}
$$

Adapun kriteria interpretasi yang peneliti gunakan adalah sebagai berikut:

\section{Tabel 1. Kriteria Interpretasi}

\begin{tabular}{lll}
\hline No. & Presentase & Kriteria \\
\hline 1. & $81-100 \%$ & Sangat baik \\
\hline 2. & $61-80 \%$ & Baik \\
\hline 3. & $41-60 \%$ & Cukup baik \\
\hline 4. & $21-40 \%$ & Kurang baik \\
\hline 5. & $0-20 \%$ & Sangat tidak baik \\
\hline
\end{tabular}

Sumber: Ridwan (ridwan, 2012)

Selanjutnya untuk melihat kepraktisan media video peneliti menggunakan rumus:

$$
x=\frac{2 x}{n}
$$

Menurut Ridwan (2012:13) melihat kepraktisan media dapat diaanalisis dengan kriteria sebagai berikut:

$$
\begin{aligned}
& 5=\text { Sangat Praktis } \\
& 4=\text { Praktis } \\
& 3=\text { Cukup Praktis } \\
& 2=\text { Kurang Praktis } \\
& 1=\text { Tidak Praktis }
\end{aligned}
$$

Kemudian rumus yang digunakan untuk mendapatkan hasil validitas media ialah:

$$
t=\frac{m d}{\sqrt{\frac{\sum x^{2} d}{N(N-1)}}}
$$

\section{Hasil dan Pembahasan}

\section{Hasil Pengembangan}

\section{Tahap analisis pengembangan media}

Tahap ini peneliti terlebih dahulu melakukan pencarian informasi yang dijadikan sebagai bahan membuat produk diantaranya analisis kurikulum dan karakteristik peserta didik. Pemilihan produk harus sesuai dengan sasaran, pada penelitian ini peneliti memilih mengembangkan media pembelajaran berbasis video dengan materi inegrasi sosial didasarkan menurunnya kualitas moral dalam kehidupan manusia Indonesia dewasa ini, terutama di 
kalangan peserta didik, menuntut pentingnya penyadaran pada peserta didik bahwa dalam kehidupan bermasyarakat perlu dijaga harmonisasi sosial. Salah satu cara agar peserta didik mengetahui bagaimana cara mengendalikan konflik dan penyimpangan untuk bersatunya unsurunsur sosial yang berbeda dengan mempelajari integrasi sosial termasuk didalamnya definisi, jenis, faktor pendorong dan penghambat inegrasi sosial. Selain itu guru juga secara tidak langsung sudah menanamkan nilai karakter kepada peserta didiknya. Dengan dibekali kecakapan ini sebagai tambahan kecakapan akademik peserta didik akan terbantu memecahkan permasalahan individual dan sosial yang dihadapi dalam kehidupan di lingkungannya (Sylvia et al., 2019). Peneliti juga melakukan analisis karakteristik peserta didik sebelum membuat rencana pengembangan media video Menurut studi pendahuluan yang telah dilakukan pada JuliDesember 2019 di kelas XI SMAN 1 Payakumbuh, peserta didik cenderung hanya menggunakan LKPD dan buku sumber yang tidak mengakomodir semua peserta didik. Peserta didik jarang menggunakan media yang bervariasi guna meningkatkan ketertarikan dan tidak memiliki keinginan lebih dalam memahami materi pembelajaran khususnya materi integrasi sosial.

\section{Tahap Perencanaan (design)}

Langkah-langkah yang peneliti lakukan dalam merencanakan produk yang dibuat adalah: (1) Membuat naskah yang akan dijadikan video pembelajaran dlam hal ini naskah berupa gagasan materi berawalkan sebuah fakta lalu berikutnya materi yang disampaikan ahlinya. (2) Menyiapkan video tambahan dalam hal ini peneliti mengambil video dari youtube. (3) Melakukan proses rekam video menggunakan kamera Sony a7ii yang dilakukan di sekitar kampus. (4) Lalu video di edit dengan memakai aplikasi Adobe premiere pro cc.

\section{Tahap Pengembangan (Development)}

\section{Tahap validitas produk}

\section{Uji Validitas Media}

Validitas media diuji oleh Dr. Erianjoni, S.Sos., M,Si dan AB. Sarca Putera, S.Ikom., M.A selaku dosen Sosiologi UNP. Hasil validasi media video yang peneliti kembangkan adalah sebagi berikut :

\section{Tabel 2. Hasil Uji Validasi Penilaian Ahli Media}

\begin{tabular}{|c|c|c|c|c|}
\hline \multirow{2}{*}{ No } & \multirow{2}{*}{ Aspek } & \multirow{2}{*}{ Indikator } & \multicolumn{2}{|c|}{ Skor validitas } \\
\hline & & & Ahli 1 & Ahli 2 \\
\hline \multirow[t]{3}{*}{1.} & \multirow[t]{3}{*}{ Fungsi dan Manfaat } & $\begin{array}{l}\text { Mampu memperjelas dan mempermudah untuk } \\
\text { penyampaian pesan dalam pembelajaran } \\
\text { sosiologi }\end{array}$ & 4 & 4 \\
\hline & & $\begin{array}{l}\text { Mampu membangkitkan minat dan motifasi } \\
\text { siswa }\end{array}$ & 4 & 3 \\
\hline & & $\begin{array}{l}\text { Mampu membangkitkan kemampuan berpikir } \\
\text { kritis siswa }\end{array}$ & 5 & 3 \\
\hline \multicolumn{5}{|c|}{ Jumlah nilai validitas $77 \%$} \\
\hline \multirow{5}{*}{\multicolumn{2}{|c|}{ 2. Media Visual }} & $\begin{array}{l}\text { Warna, background, gambar dan video yang } \\
\text { dipilih menarik }\end{array}$ & 5 & 4 \\
\hline & & video sesuai dengan pengambilan ukuran & 4 & 4 \\
\hline & & Gambar dan materi dapat terlihat dengan jelas & 4 & 2 \\
\hline & & Ketepatan pencahayaan gambar & 5 & 4 \\
\hline & & Kecepatan gerakan gambar telah sesuai & 4 & 4 \\
\hline
\end{tabular}


Sriyani Amsar, Ike Sylvia, AB Sarca Putera

Pengembangan Video Sebagai Media Pembelajaran Dalam Meningkatkan Kemampuan Berpikir Analisis Siswa Pada Pembelajaran Sosiologi Kelas XI IPS SMA N 1 Payakumbuh

\begin{tabular}{|c|c|c|c|c|}
\hline \multicolumn{5}{|c|}{ Jumlah nilai validitas $80 \%$} \\
\hline \multirow[t]{3}{*}{3.} & \multirow[t]{3}{*}{ Audio media } & Ritme suara yang disajikan narator sesuai & \multirow{2}{*}{$\begin{array}{l}4 \\
5\end{array}$} & \multirow{2}{*}{$\begin{array}{l}3 \\
3\end{array}$} \\
\hline & & $\begin{array}{l}\text { Suara narator terdengar dengan jelas dan } \\
\text { informative }\end{array}$ & & \\
\hline & & Suara music sesuai dengan tampilan gambar & 4 & 4 \\
\hline \multicolumn{3}{|c|}{ Jumlah nilai validitas $77 \%$} & & \\
\hline \multirow[t]{2}{*}{4.} & \multirow[t]{2}{*}{ Aspek tipografi } & Jenis teks mudah dibaca & 4 & 2 \\
\hline & & Ukuran teks sudah sesuai & 5 & 2 \\
\hline \multicolumn{5}{|c|}{ Jumlah nilai validitas $65 \%$} \\
\hline 5. & Aspek bahasa & Bahasa mudah dipahami siswa & 5 & 4 \\
\hline
\end{tabular}

\section{Sumber: Data primer 2020}

Berdasarkan hasil validasi media oleh pakar, pada variabel fungsi dan manfaat yang memiliki 3 indikator mendapat rata-rata 3,83 dengan nilai validitas $77 \%$, sedangkan untuk variabel visual Media yang memiliki 5 indikator mendapat rata-rata 4,00 dengan nilai validitas $80 \%$, untuk variabel Audio Media dengan 3 indikator mendapat rata-rata 3,83 dengan nilai validitas $77 \%$, untuk variabel tipografi yang memiliki 2 indikator mendapat rata-rata 3,25 dengan nilai validitas $65 \%$, untuk variabel bahasa yang memiliki 1 indikator mendapat rata-rata 4,50 dengan nilai validitas $90 \%$ Secara keseluruhan aspek media dari validator mendapat ratarata 3,88 dengan nilai validitas $77,8 \%$ yang arti berada pada kriteria "baik "

\section{Uji Validitas Materi}

Tabel 3. Penilaian Ahli Media

\begin{tabular}{|c|c|c|c|}
\hline No & Aspek & Indikator & $\begin{array}{c}\text { Skor } \\
\text { validitas }\end{array}$ \\
\hline \multirow[t]{2}{*}{1.} & \multirow[t]{2}{*}{$\begin{array}{l}\text { Relevansi materi } \\
\text { dengan silabus }\end{array}$} & $\begin{array}{l}\text { Materi yang disajikan sesuai dengan yang terkandung } \\
\text { dalam standar kompetensi dan kompetensi dasar }\end{array}$ & 5 \\
\hline & & Materi yang disajikan sesuai dengan isi silabus & 5 \\
\hline \multicolumn{4}{|c|}{ Jumlah nilai validitas $100 \%$} \\
\hline \multirow[t]{2}{*}{2.} & \multirow[t]{2}{*}{ Kualitas materi } & Materi yang disajikan jelas & 4 \\
\hline & & Materi yang digunakan sudah tepat & 5 \\
\hline & & Jumlah nilai validitas $90 \%$ & \\
\hline \multirow[t]{3}{*}{3.} & Bahasa & Bahasa yang digunakan dalam materi sudah tepat & 5 \\
\hline & & Teks dalam materi sudah tepat & 4 \\
\hline & & $\begin{array}{l}\text { Bahasa yang digunakan adalah bahasa yang mudah } \\
\text { dipahami }\end{array}$ & 3 \\
\hline
\end{tabular}

Jumlah nilai validitas $80 \%$

Berdasarkan hasil validitas materi yang dilakukan oleh guru sebagai validator pada variabel pertama yaitu Aspek relevansi materi dengan silabus mendapat 2 indikator dengan ratarata 5,00 dengan nilai validitas $100 \%$, untuk variabel kualitas materi dengan rata-rata 4,50 dengan nilai validitas $90 \%$, variabel Kebahasaan yang memiliki 3 indikator diperoleh rat-rata $4,00 \%$ dengan validitas $80 \%$. Dari beberapa variabel diatas diperoleh rata-rata 4,50 dengan nilai validitas $90 \%$ yang artinya berada pada kriteria "sangat baik". 


\section{Uji Praktikalitas Media}

Data hasil uji coba praktikalitas media video dilihat dari (1) Penguasaan Materi yang Terdiri dari 2 indikator, (2) Kemudahan Penggunaan yang terdiri dari 3 indikator, (3) Manfaat yang memiliki 4 indikator, (4) Tampilan terdiri dari 2 indikator, (5) Waktu, terdiri dari 3 indikator. Adapun perhitungan praktikalitas Media Video pada materi Integrasi Sosial dapat dilihat pada tabel berikut:

\section{Tabel 4. Uji Praktikalitas Media}

\begin{tabular}{|c|c|c|c|}
\hline Aspek & Indikator & Rata-Rata & Keterangan \\
\hline \multirow[t]{2}{*}{$\begin{array}{l}\text { 1. Penguasaan } \\
\text { materi }\end{array}$} & $\begin{array}{l}\text { Materi yang disajakan mudah untuk } \\
\text { dipahami }\end{array}$ & \multirow{2}{*}{4,45} & \multirow{2}{*}{$\begin{array}{l}\text { Sangat } \\
\text { Praktis }\end{array}$} \\
\hline & $\begin{array}{l}\text { Pesan yang disampaikan diterima dengan } \\
\text { jelas }\end{array}$ & & \\
\hline \multirow[t]{3}{*}{$\begin{array}{l}\text { 2. Kemudahan } \\
\text { penggunaan }\end{array}$} & $\begin{array}{l}\text { Terdapat kemudahan dalam penggunaan } \\
\text { media }\end{array}$ & \multirow{3}{*}{4,17} & \multirow{3}{*}{$\begin{array}{l}\text { Sangat } \\
\text { Praktis }\end{array}$} \\
\hline & $\begin{array}{l}\text { Kejelasan alur pembelajaran mudah } \\
\text { dimengerti }\end{array}$ & & \\
\hline & Bahasa yang digunakan mudah dipahami & & \\
\hline \multirow[t]{4}{*}{ 3. Manfaat } & $\begin{array}{l}\text { Media yang digunakan bisa meningkatkan } \\
\text { kemampuan berpikir analisis siswa }\end{array}$ & \multirow{4}{*}{4,00} & \multirow{4}{*}{$\begin{array}{l}\text { Sangat } \\
\text { Praktis }\end{array}$} \\
\hline & Bisa meningkatkan minat belajar siswa & & \\
\hline & $\begin{array}{l}\text { Bisa memberikan bantuan dalam proses } \\
\text { pembelajaran }\end{array}$ & & \\
\hline & $\begin{array}{l}\text { Media bisa digunakan untuk belajar } \\
\text { mandiri }\end{array}$ & & \\
\hline \multirow[t]{2}{*}{ 4. Tampilan } & Teks dapat dibaca dengan baik & \multirow{2}{*}{4,20} & \multirow{2}{*}{$\begin{array}{l}\text { Sangat } \\
\text { Praktis }\end{array}$} \\
\hline & Tampilan gambar menraik & & \\
\hline \multirow[t]{3}{*}{ 5. Waktu } & $\begin{array}{l}\text { Waktu yang digunakan dalam } \\
\text { pembelajaran singkat }\end{array}$ & \multirow{3}{*}{4,20} & \multirow{3}{*}{$\begin{array}{l}\text { Sangat } \\
\text { Praktis }\end{array}$} \\
\hline & $\begin{array}{l}\text { Materi yang disajikan sesuai dengan waktu } \\
\text { yang tersedia }\end{array}$ & & \\
\hline & $\begin{array}{l}\text { Soal tes yang diberikan sesuai dengan } \\
\text { waktu yang tersedia }\end{array}$ & & \\
\hline
\end{tabular}

\section{Uji Efektivitas Media}

Uji efektivitas produk dilaksanakan pada kelas XI IPS 2 SMAN 1 Payakumbuh. Karena menggunakan desain eksperimen one group pretest and posttest maka uji coba produk dilakukan pada satu kelas saja. Berdasarkan hasil uji efektivitas thitung sebesar 10,63 dan ttabel dengan df $=\mathrm{N}-1$ atau 33-1 $=32$ dengan $\alpha$ 0,05 maka t tabel 2,036 sehingga $t$ hitung $>$ dari t tabel. Artinya terdapat perbedaan yang signifikan antara hasil pre test dan post test siswa sebelum menggunakan media video dan setelah menggunakan media video materi integrasi sosial. Kesimpulan penelitian ini adalah media video yang dikembangkan pada pembelajaran sosiologi valid, praktis dan efektif serta berpengaruh terhadap peningkatan berpikir analisis peserta didik terhadap materi integrasi sosial. 


\section{Pembahasan}

Pengembangan media pembelajaran berbasis video pada materi integrasi sosial dapat memberikan terobosan baru guna meningkatkan kemampuan berpikir analisis siswa. Hal ini selaras yang dikemukan Azhar Arsyad (Arsyad, 2011) menyatakan bahwa media audio visual ialah media yang dapat mengaktifkan indra mata dan telinga dalam waktu bersamaan pada proses belajar mengajar berlangsung. Hasil penelitian ini selaras dengan dengan penelitian yang dilakukan (Jumriani, 2018) dalam efektifitas penggunaan media video dalam penulisan hasil penelitiannya dapat diketahui bahwa media berbasis audio visual sangat efektif digunakan dalam meningkatkan hasil pembelajaran kaitannya dalam penelitian ini adalah bahwa media audio visual baik untuk proses maupun hasil pembelajaran. Dari segi proses media audio visual sangat efektif untuk proses pembelajaran sedangkan dari segi hasil dapat membantu siswa mencapai tujuan pembelajaran yang ditetapkan.

Penutup

Media video yang dikembangkan layak digunakan dalam meningkatkan kemampuan berpikir analisis peserta didik pada materi integrasi sosial pada pembelajaran sosiologi kelas XI. Berdasarkan hasil validasi ahli media dan ahli materi, media video memenuhi kriteria kelayakan "Sangat layak". Berdasarkan hasil uji coba awal, media pembelajaran berbasis video memenuhi kriteria kelayakan dengan kategori "sangat layak" dari hasil angket respon guru dan kategori "sangat layak" dari hasil angket respon siswa. Berdasarkan hasil uji coba lapangan produk, media video integrasi sosial memenuhi kriteria efektifitas dengan kategori "sangat efektif" dan "sangat praktis" dari hasil angket respon guru dan angket respon siswa. Hasil uji-t independen menunjukkan bahwa terdapat perbedaan kemampuam berpikir peserta didik sebelum dan sesudah menggunakan media video dalam pembelajaran integrasi sosial, dengan nilai signifikansi $(\mathrm{p})<0,05$ yaitu sebesar 0,000. dengan nilai thitung sebesar 10,63 dan ttabel dengan $\mathrm{df}=\mathrm{N}-1$ atau 33-1 = 32 dengan $\alpha$ 0,05 maka t tabel 2,036 sehingga $\mathrm{t}$ hitung $>$ dari t tabel.

\section{Daftar Pustaka}

Arsyad, A. (2011). Media Pembelajaran. Jakarta: PT Raja Grafindo Persada.

Branch, R. M. (2009). Instructional Design-The ADDIE Approach. New York: Springer.

Putri, K. E, \& Sutrisno, S. (2013). Pengembangan Media Pembelajaran Berbasis Android Pada Mata Kuliah Pembelajaran Terpadu. Chemical Information and Modeling, 9(1), 1689-1699.

Harjanto, H. (2005). Perencanaan Pengajaran. Jakarta: Rineka Cipta.

Jumriani, J. (2018). Pengembangan Video Pembelajaran Berbasis Domain IPA dan Sikap Ilmiah Peserta Didik. Thesis. Universitas Negeri Yogyakarta.

Marjohan, M. (2013). Kepatuhan Siswa terhadap Disiplin dan Upaya Guru BK dalam Meningkatkanya melalui Layanan Informasi. Ilmiah Konseling, 2(5), 220-224.

Munir, M. (2012). Multimedia Konsep \& Aplikasi Dalam Pendidikan. Bandung: Alfabeta.

Munthe, M. (2009). Design Pembelajaran. Yogyakarta: Insan madani.

Niswah, A. (2012). Pengembangan Bahan Ajar Mendengarkan Berbasis Video Interaktif Bermedia Flash Kelas VII SMP Negeri 1 Kedamean. Skripsi. Universitas Negeri Surabaya.

Putra, N. (2012). Reseacrh and Development. Jakata: Raja Grafindo Persada.

Ridwan, R. (2012). Skala Pengukuran Variabel-variabel Penelitian. Bandung: Alfabeta.

Rusman, R. (2013). Model-model Pembelajaran. Jakarta: Raja Grafindo Persada.

Sanjaya, W. (2009). Perencanaan dan Desain Sistem Pembelajaran. Jarkata: Kencana Prenada Media Groub.

Sugiyono, S. (2013). Metode Penelitian Kuantitatif, Kualitatif, dan R\&D. Bandung: Alfabeta.

Sukiman, S. (2012). Pengembangan Media Pembelajaran. Yogyakarta: Pedagogia.

Jurnal Sikola: Jurnal Kajian Pendidikan dan Pembelajaran Vol. 2, No. 1, Th. 2020 
Sylvia, I., Anwar, S., Khairani, K. (2019). Pengembangan Instrumen Penilaian Autentik Berbasis Pendekatan Authentic Inquiry Learning pada Mata Pelajaran Sosiologi di Sekolah Menengah Atas. Socius, 6(2), 103-120.

Vermana, D. Y., \& Sylvia, I. (2019). Penerapan Model Group Investigation Dalam Meningkatkan Kemampuan Kerjasama Siswa Kelas XI IPS di SMAN 6 Padang. Jurnal Sikola: Jurnal Kajian Pendidikan dan Pembelajaran, 1(1), 60-68. 